\title{
Bone Marrow Iron Staining is a Reliable Test for Elimination of Iron Deficiency Anemia Rather than its Diagnosis
}

\author{
Ebru KOCA ${ }^{1}$, Deniz A. CETINER ${ }^{2}$, Yahya BUYUKASIK ${ }^{3}$, Aysegul UNER ${ }^{4}$, Nilgun SAYINALP², \\ Ibrahim C. HAZNEDAROGLU ${ }^{3}$, Hakan GOKER ${ }^{3}$, Salih AKSU ${ }^{3}$, Osman I. OZCEBE ${ }^{3}$
}

\author{
Baskent University Faculty of Medicine, Department of Hematology, Ankara \\ ${ }^{2}$ Okmeydani Training and Research Hospital, Department of Hematology, Istanbul \\ ${ }^{3}$ Hacettepe University Faculty of Medicine, Department of Hematology, Ankara \\ ${ }^{4}$ Hacettepe University Faculty of Medicine, Department of Pathology, Ankara, TURKEY
}

\begin{abstract}
Iron deficiency anemia (IDA) is the most frequent type of anemia. The use of biochemical markers is a challenging way of diagnosis in case of inflammation and functional iron deficiency. The role of bone marrow aspirate iron staining is criticized because it is an invasive method and has no accurate standardization. This study was planned to find the value of bone marrow iron staining in diagnosis of iron deficiency. Four hundred and seven cases who had bone marrow aspirate iron staining and simultaneous serum iron tests have been reviewed retrospectively and 47 such cases were evaluated prospectively. Bone marrow iron was negative in 125 (\%30.7) cases in retrospective cohort. There was significant differences in serum iron, ferritin, transferrin saturation between bone marrow iron negative and positive cohorts $(p<0.001)$. Low serum transferrin saturation $(<15 \%)$ and ferritin $(<15 \mathrm{ng} / \mathrm{ml})$ levels are consistent with iron deficiency. On this standard, in both retrospective and prospective cohorts, rates for specificiy $(85.5 \%$ and $90.4 \%$, respectively) and negative predictivity ( $97.5 \%$ and $100 \%$, respectively) of bone marrow iron staining were relatively high compared with the sensitivity and positive predictivity of the same test. The results of this study show that the evaluation of bone marrow iron staining is a more reliable test for the elimination of IDA rather than its diagnosis.
\end{abstract}

Keywords: Iron deficiency anemia, Ferritin, Bone marrow iron staining, Diagnosis

\section{ÖZET}

Kemik iliği Demir Boyası Demir Eksikliği Anemisinin Teşhisinden Çok Dışlanması İçin Güvenilir Bir Yöntemdir

Demir eksikliği anemisi en sık görülen anemidir. İnflamasyon ve fonksiyonel demir eksikliği olması durumlarında biyokimyasal belirteçler kullanıırken tanıda zorluklarla karşılaşıı. Kemik ilı̆ginde demir boyanmasının rolü invazif olması ve doğru standardizasyonunun bulunmaması nedeniyle eleştirilmektedir. Bu çalışma demir eksikliğinde kemik iliğinde demir boyanmasının değerini belirlemek amacıyla planlanmıştır. Kemik iliği demir boyası ile eşzamanlı demir testleri bulunan 407 vaka retrospektif olarak, 47 vaka prospektif olarak incelendi. Retrospektif kohortta 125 (\%30.7) vakada kemik iliği demiri negatifti. Kemik iliği demiri pozitif ve negatif olan gruplar arasında serum demir, ferritin, transferin ve transferin saturasyonlarında anlamlı olarak $(p<0.001)$ fark vardı. Düşük serum transferin saturasyonu (<\%15) ve ferritin $(<15 \mathrm{ng} / \mathrm{ml})$ seviyeleri demir eksikliği ile uyumluydu. Bu standardlara göre retrospektif ve prospektif kohortlarda kemik iliği demir boyasının özgülük (\%85.5 ve \%90.4, sırasıyla) ve negatif prediktif (\%97.5 ve \%100, sırasıyla) değerleri aynı testin duyarlıık ve pozitif prediktif değerlerine göre yüksek bulundu. Bu çalışmanın sonuçları kemik iliği demir boyasının demir eksikliği anemisi tanısından çok dışlanması için güvenilir bir yöntem olduğunu göstermektedir.

Anahtar Kelimeler: Demir eksikliği anemisi, Ferritin, Kemik iliği demir boyası, Teşhis 


\section{INTRODUCTION}

Serum iron parameters are generally sufficient for diagnosis of iron deficiency anemia (IDA). Presence of both low serum transferrin saturation (saTf) and decreased serum ferritin levels in an anemic patient is consistent with iron deficiency. In some occasions these parameters may be at borderline or not informative due to associated disorders. In these gray zone conditions, a definite diagnosis of iron deficiency by the conventional serum iron tests is impossible. In these cases, either bone marrow iron staining for diagnostic confirmation or empirical iron replacement are generally used in clinical practice. The value of bone marrow iron staining has been criticized due to invasiveness and lower-thanexpected positive predictivity of absent bone marrow iron in retrospective studies. ${ }^{1-3}$ The reasons of the lower-than-expected positive predictivity is not clear. If inappropriate marrow specimens and inexpert interpreter are the reasons, these should not be considered as failures of the method. In this study, we evaluated correctness of bone marrow iron stain reports in our routine clinical practice and prospectively investigated whether ideal conditions could improve correctness of the test.

\section{PATIENTS AND METHODS}

In the retrospective phase of the study, all bone marrow aspiration reports indicating iron stain results between March 2002 and May 2007 were screened in a prospectively maintained department database. These patients were evaluated if serum iron tests had been studied within two weeks of bone marrow aspiration from hospital laboratory database. The retrospective study population composed of patients who had simultaneous marrow iron stain and serum iron tests. The patients who had received iron therapy between the serum tests and bone marrow sampling were eliminated. In the prospective cohort, all bone marrow aspiration crush smears made between July 2007 and March 2008 and ordered to be stained for iron by a treating physician were stained for iron using the Prussian blue technique with a strictly defined staining procedu$\mathrm{re}^{4}$ and evaluated for adequacy (defined as presence of at least 4 particles on gross visual inspection), and if adequate, assessed for storage iron by an experienced hematologist (YB). Serum iron tests after at least 8 hours' fasting were required to be tested or they were ordered within 2 weeks of bone marrow sampling and it was confirmed that the patients had not received iron medications within this period. Iron staining procedure was briefly as follows: air-dried crush smears were fixed in formalin vapor. Equal volumes of $4 \%$ hydrochloric acid and $4 \%$ potassium ferrocyanide solutions were mixed in a staining jar. The mixture was heated to $56^{\circ} \mathrm{C}$ and the slides immersed in the solution. After 30 minutes, the slides were rinsed in tap water. They were counterstained for 5 minutes by haematoxylin. Bone marrow iron staining was graded as negative or positive, between $1+$ and $4+$. Positivities of various grades were lumped together for statistical analyses. Serum iron tests were considered as compatible with IDA if both serum ferritin level $(<15 \mathrm{ng} / \mathrm{ml})$ and saTf $(<15 \%)$ were decreased. The tests were incompatible with iron deficiency if both of them were above specified thresholds, $>20 \mathrm{ng} / \mathrm{ml}$ and $>20 \%$, respectively. Other patients, including those who were not anemic in spite of IDA-compatible serum iron tests, were considered to have indeterminate results. Correctness of bone marrow iron stain reports were analyzed using only the patients with iron deficiency-compatible and incompatible test results. Sensitivity, specificity, positive and negative predictivities of bone marrow iron staining were calculated both in the retrospective and prospective cohorts. Statistical Packages For The Social Sciences v10 (SPSS Inc., Chicago, IL) software was for data management.

\section{RESULTS}

There were 407 and 47 patients in the retrospective and prospective cohorts, respectively. Two hundred and eighty two $(69.2 \%)$ cases in the retrospective and $39(83 \%)$ in the prospective cohorts were reported to have positive bone marrow iron. Figure 1 depicts a picture of positive and negative bone marrow iron staining. Two hundred and forty six patients in retrospective and 23 patients in prospective cohorts were not included in further statistical analyses as they had indeterminate serum iron test results. The patients with negative bone marrow iron had lower serum iron, saTf, ferritin and higher TIBC results compared to those with positive iron ( $p<0.001$ for all comparisons, data not presented).

There were 20 cases with serum iron tests considered compatible with IDA and 141 cases incompa- 


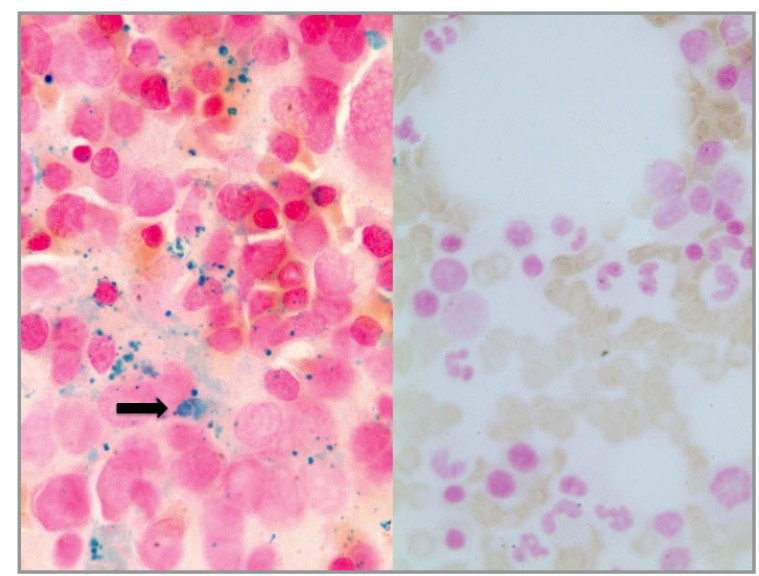

Figure 1. Prussian-blue staining of bone marrow. Positive iron stores (arrow) seen on left and negative on right

tible in the retrospective cohort (Table 1). In prospective cohort, only 3 cases were considered compatible and 21 incompatible with IDA (Table 2). Sensitivity of the iron staining was $85 \%$ and specificity $85.8 \%$ in retrospective cohort (Table 3 ). Negative predictive value was $97.5 \%$ while positive predictivity was $45.9 \%$. In prospective cohort, sensitivity was $100 \%$ and specificity $90.4 \%$. Negative predictivity was $100 \%$ while positive predictive value was $60 \%$.

\section{DISCUSSION}

There is still no single biochemical parameter that can be used as a comprehensive indicator of iron status. ${ }^{5}$ In many clinical conditions such as chronic infection, rheumatoid arthritis, liver diseases, hematologic malignant disorders, classic indices like serum iron, transferin saturation and ferritin concentration are not valid indicators of iron deficiency. Examination of bone marrow smears for stainable iron has proved to be a reliable method of detecting iron depleted states ${ }^{6,7}$ despite contrary observations ${ }^{8-10}$ Many physicians continue to consider bone marrow aspiration stained with prussian-blue as the gold standard in evaluating iron deficiency. Although very few studies have examined the accuracy of the test, the value of other biochemical indices has been weighed mostly against this standard. ${ }^{1}$ Our observation suggests that reliability of bone marrow iron examination increases when ideal conditions are obtained. We found a very high negative predictivity of the test even reaching to $100 \%$ in prospective cohort. But, positive predictivity was not that high in both cohorts. It can be concluded that bone marrow iron examination is a valuable test for excluding IDA rather than diagnosis in patients with indeterminate biochemical indices. In our opinion bone marrow iron examination is still important in clinical practice. It is possible to exclude IDA with bone marrow examination in most of the patients with indeterminate peripheral blood iron results instead of giving empirical iron therapy. Thus, in 20 (87\%) of 23 patients with indeterminate serum iron indices in prospective cohort and $158(64.2 \%)$ of 246 patients in retrospective cohort had positive iron stores in bone marrow and IDA was excluded.

\begin{tabular}{|c|c|c|c|c|}
\hline & & \multicolumn{2}{|c|}{ Iron } & \multirow[t]{2}{*}{ Total } \\
\hline & & Negative & Positive & \\
\hline \multirow[t]{3}{*}{ IDA-status } & IDA-compatible & 17 & 3 & 20 \\
\hline & IDA-incompatible & 20 & 121 & 141 \\
\hline & Indeterminate & 88 & 158 & 246 \\
\hline Total & & 125 & 282 & 407 \\
\hline
\end{tabular}

\begin{tabular}{|c|c|c|c|c|}
\hline & & \multicolumn{2}{|c|}{ Hemosiderin } & \multirow[t]{2}{*}{ Total } \\
\hline & & Negative & Positive & \\
\hline \multirow[t]{3}{*}{ IDA-status } & IDA-compatible & 3 & 0 & 3 \\
\hline & IDA-incompatible & 2 & 19 & 21 \\
\hline & Indeterminate & 3 & 20 & 23 \\
\hline Total & & 8 & 39 & 47 \\
\hline
\end{tabular}




\begin{tabular}{|lll|}
\hline Table 3. Correctness of bone marrow iron reporting in the retrospective and prospective cohorts. \\
\hline & $\begin{array}{l}\text { Retrospective cohort } \\
\mathbf{n = 1 6 1}\end{array}$ & $\begin{array}{l}\text { Prospective cohort } \\
\mathbf{n = 2 4}\end{array}$ \\
\hline Sensitivity & $17 / 20(85 \%)$ & $3 / 3(100 \%)$ \\
Specificity & $121 / 141(85.8 \%)$ & $19 / 21(90.4 \%)$ \\
Positive predictive value (\%) & $17 / 37(45.9 \%)$ & $3 / 5(60 \%)$ \\
Negative predictive value (\%) & $121 / 124(97.5 \%)$ & $19 / 19(100 \%)$ \\
\hline
\end{tabular}

Another biochemical index for IDA, serum transferrin receptor, has shown to be diagnostically superior to ferritin especially in patients with inflammatory diseases ${ }^{5}$ but it cannot be used widely because of its lack of standardization and there are conflicting results in heterogeneous group of patients..$^{11,12}$

It is expected that bone marrow iron stores would become positive after iron replacement therapy and iron indices normalize. ${ }^{13}$ To our knowledge there is no study in literature showing alterations in bone marrow histology related to dose and period of oral iron therapy. In our study we did not have the data of iron treatment dose and period if patients had any.

One of the handicaps of our study is, we assumed that bone marrow iron results of patients with indeterminate blood tests were as good as results of patients with IDA compatible and incompatible. This might not be true. Another handicap is we determined $15 \mathrm{ng} / \mathrm{ml}$ ferritin threshold for IDA independent of the gender. It is arguable that this value is low, but we found it appropriate to define such a low value so IDA compatible group would only include definitely iron deficient patients. IDA compatible patient number decreased considerably after excluding indeterminate patients in prospective cohort related to this threshold. Nonetheless, our observations emphasize bone marrow iron staining is a reliable method for elimination of iron deficiency anemia especially in complicated states. In addition, ideal conditions improve the correctness of the test.

\section{REFERENCES}

1. Barron B, Hoyer JD, Tefferi A. A bone marrow report of absent stainable iron is not diagnostic of iron deficiency. Ann Hematol 80: 166-169, 2001.

2. Ganti AK, Moazzam N, Laroia S, et al. Predictive value of absent bone marrow iron stores in the clinical diagnosis of iron deficiency anemia. In vivo 17: 389-392, 2003.

3. Fong TP, Okafor LA, Thomas W Jr, et al. Stainable iron in aspirated and needle biopsy specimens of marrow: a source of error. Am J Hematol 2:47-451, 1977.
4. Beutler E. Blood, marrow, and urine iron stains. In: Williams Hematology, 5th edition. (Beutler E, Lichtman MA, Coller BS, Kipps TJ, eds). New York, McGraw-Hill Inc., 1995; pp L27.

5. Brugnara C. Iron deficiency and erythropoiesis: new diagnostic approaches. Clin Chem 49: 1573-1578, 2003.

6. Beutler E. Clinical evaluation of iron stores. New Eng J Med 256: 692-697, 1957.

7. Bainton DF, Finch CA. The diagnosis of iron deficiency anemia. Am J Med 37: 62-70, 1964.

8. Cervantes F, Marti JM, Lopez-Guillermo A, et al. Iron stores in essential thrombocythameia. A study of 26 patients. Blut 58: 291-294, 1989.

9. Cervantes F, Rozman C, Piera C, et al. Decreased bone marrow iron in chronic granulocytic leukaemia: a consistent finding not reflecting iron deficiency. Blut 53: 305-308, 1986.

10. Engel JP, Schein OD, Conley CL. Bone marrow iron does not always reflect body iron stores. Arch Intern Med 142: 287-288, 1982.

11. Mast AE, Blinder MA, Gronowski AN, et al. Clinical utility of the soluble transferrin receptor and comparison with serum ferritin in several populations. Clin Chem 44: 45-51, 1998.

12. Chang J, Bird R, Clague A, et al. Clinical utility of serum soluble transferrin receptor levels and comparison with bone marrow iron stores as an index for iron deficient erythropoiesis in a heterogeneous group of patients. Pathology 39: 349-353, 2007.

13. Johnson-Wimbley TD, Graham DY. Diagnosis and management of iron deficiency anemia in the 21st century. Therap Adv Gastroenterol 4: 177-184, 2011.

\section{Correspondence}

Dr. Ebru KOCA

Başkent Üniversitesi Tıp Fakültesi

Hematoloji Bilim Dalı

M. Fevzi Çakmak Cad. No:48

06490 Bahçelievler, ANKARA / TURKEY

Tel: (+90.312) 2122912

Fax: (+90.312) 2150987

e-mail: ebrukoca@gmail.com

ebruk@baskent-ank.edu.tr 